\title{
Chemotherapy Effects on the Activities of Some Purine Metabolic Enzymes in Sera of Ovarian Cancer Patients
}

\author{
Shatha Abd AL-Wadood Al-Shammaree* \\ Received 1, October, 2006 \\ Acceptance 4, August, 2009
}

\begin{abstract}
:
Adenosine deaminase (ADA; Ec: 3.5.4.4), 5'- Nucleotidase (5'- NT; Ec: 3.1.3.5), and AMP - amino hydrolase (AMP - deaminase AMPDA; Ec: 3.5.4.6) activities were measured in sera of ovarian cancer patients before surgery, and after chemotherapy.

The results indicated that ADA specific activity increased significantly $(\mathrm{P}<0.05)$, while $5^{\prime}-\mathrm{NT}$ and AMPDA specific activity decreased significantly $(\mathrm{P}<0.05)$ in ovarian cancer patients before surgery in comparison with those of their corresponding control women and benign tumors groups.

When the activities of these enzymes were measured after chemotherapy, a significant decrease $(\mathrm{P}<0.05)$ in ADA activity, and a significant increase $(\mathrm{P}<0.05)$ in $5^{\prime}-\mathrm{NT}$ and AMPDA activities were found in comparison with those before surgery.
\end{abstract}

Key words: Adenosine deaminase (ADA); 5'-Nucleotidase (5'-NT); AMP deaminase (AMPDA); ovarian cancer; chemotherapy.

\section{Introduction:}

In cancer cells, a marked imbalance in the enzymatic pattern of purine metabolism is linked with, transformation and / or progression of the disease. The molecular correlation concept applies to purine biochemistry, and an important segment of neoplastic gene expression was identified in the behavior of key purine metabolizing enzymes[1,2] .Even though cancer cells are abnormal, it has proved that difficult to find general, exploitable differences between them and normal body cells[3].

Chemotherapy of cancer presents a difficult problem, in finding agents with selective toxicity for cancer cell. Most anticancer drugs are antiproliferative agents, and will also effect rapidly dividing normal cells, consequently they are likely to: depress bone marrow, impair healing, depress growth, cause sterility and hair loss[3] .
The physiological nucleoside adenosine plays a key role in the regulation of multiple physiological processes, including cardiovascular and renal function, and neurotransmission[4,5,6,7]. Also growth regulation of vascular system (angiogenesis) is one of the roles played by adenosine in human body. [8]

Nucleotides are also responsible for the uptake of nucleoside analog drugs used in the treatment of cancer and viral infections[9], and they are the target of certain compounds used in the treatment of some types of cardiovascular disease[10]. Nucleotides also influence the pharmacokinetics and normal tissue toxicities of nucleoside drugs[11] and in cancerous tissues, the presence or absence of nucleotides influences the therapeutic effectiveness of nucleoside analogbased chemotherapy $[12,13]$.

* Depts. chemistry / College of Science / University of Baghdad. 
The new criteria of sensitivity of tumor to chemical drugs necessary for rational planning of oncology patient's chemotherapy are intensively developed. The enzymes of DNA precursor's metabolism are of certain interest because the metabolites of this process are widely used as chemotherapeutic drugs[14] .

Since most cytostatics are nucleosides analogs and generally have to be converted to their active form by one of the nucleosides introversions enzymes, more knowledge of nucleosides metabolism at the level of enzyme activities could contribute to more specific cancer chemotherapy . For example Methotrexate (a folate antagonist) and fluorouracil (5-Fu) (a pyrimidine analog) are used in cancer chemotherapy, where both of them affect nucleotides metabolism and consequently DNA synthesis and cell division[3].

In this study, Adenosine deaminase (ADA; Ec: 3.5.4.4), AMPdeaminase (AMPDA; Ec: 3.5.4.6), and $5^{\prime}$-Nucleotidase (5'-NT; Ec: 3.1.3.5) activities were measured in sera of patients with ovarian cancer in comparison with those of patients with benign ovarian tumors, before surgery, and of normal women.

Analysis of tumor marker enzymes serves as an indicator of cancer response to therapy[15]. and in order to study the effect of anticancer drugs on enzymes activities and the possibility to use them as markers for the beneficent of these drugs, the activities of these enzymes were followed before and after chemotherapy with methotrexate (in combination with folinic acid), and fluorouracil (5-Fu).

\section{Materials and methods \\ Chemicals:}

All laboratory chemicals and reagents used were of analar grade.

\section{Patients:}

A total of (30) patients suffering from ovarian tumors ages (20-71) years were used in this study, six of them were diagnosed as ovarian cancer patients, and (24) were benign ovarian tumors patients. A matching group of (27) normally healthy women ages (18-73) years were selected as controls. All patients were admitted for management to Al- Elweia teaching hospital, $\mathrm{Al}$ - Yarmook teaching hospital. The diagnosis was proven by cytological histopathological examination in these hospitals. Any patient with coexisting diseases was excluded.

Blood samples were taken from the cancer patients group before surgery, and after the first course of chemotherapy [that included methotrexate ( in combination with folinic acid ), and (5-Fu)].

\section{Samples:}

Five milliliters of blood sample were withdrawn from each woman, allowed to coagulate at room temperature before being centrifuged at $(3000 \mathrm{x} \mathrm{g})$ for (10) minutes, the resultant sera were separated and stored at $(-20){ }^{\circ} \mathrm{C}$ until used.

\section{Determination of total protein concentration:}

Total protein concentration was determined in all samples using Lowry et al. method[16], where bovine serum albumin (BSA) was used as a standard protein.

\section{Determination of ADA activity:}

ADA activity was measured
following Giusti and Galanti
method[17]. The ammonia that
produced upon ADA action on
adenosine, form an intensely blue color
with phenol and sodium hypochlorite
in an alkaline solution. The intensity of


the produced color was measured at (628) $\mathrm{nm}$.

The enzyme activity was calculated according to the following equation:

Activity $(\mathrm{U} / \mathrm{L})=\frac{\mathrm{A}-\mathrm{B}}{\mathrm{C}} \times \frac{1}{\mathrm{t}} \times \frac{1}{\mathrm{~V}_{\mathrm{s}}} \times \frac{\mathrm{V}_{\mathrm{I}}}{\mathrm{V}_{\mathrm{t}}} \times 1000$

Where:

$\mathrm{A}=\mathrm{A}_{\text {sample }}-\mathrm{A}_{\text {sample blank }}$

$\mathrm{B}=\mathrm{A}_{\text {Adenosine blank }}-\mathrm{A}_{\text {Reagent blank }}$

$\mathrm{C}=\mathrm{A}_{\text {Standard }}-\mathrm{A}_{\text {Reagent blank }}$

$\mathrm{t}=$ Incubation time

$\mathrm{V}_{\mathrm{s}}=$ Sample volume

$\mathrm{V}_{\mathrm{I}}=$ Incubation volume

$\mathrm{V}_{\mathrm{t}}=$ Total volume

For the assay, the values were as following:

$$
\begin{aligned}
(\mathrm{U} / \mathrm{L}) & =\frac{\mathrm{A}-\mathrm{B}}{\mathrm{C}} \times \frac{1}{60} \times \frac{1}{0.050} \times \frac{1.05}{7.05} \times 1000 \\
& =\frac{\mathrm{A}-\mathrm{B}}{\mathrm{C}} \times 50
\end{aligned}
$$

\section{Determination of AMPDA activity:} AMPDA activity was determined using the same procedure that was used for ADA activity, except for the buffer and substrate that were used. Since AMPDA has recorded to have an absolute requirement for potassium ions $\left(\mathrm{K}^{+}\right)$, therefore the phosphate buffer (0.05 M ; pH 6.5 ), used in the assay mixture, was modified to contain potassium chloride ( $0.025 \mathrm{M})$.

\section{Determination of $5^{\prime}$-NT activity:}

$5^{\prime}$-NT activity was measured in the serum using Wood and William's method[18]. This method depends on measuring the liberated phosphate that produced with adenosine upon the hydrolysis of $5^{\prime}$ AMP by $5^{\prime}-\mathrm{NT}$ action. This liberated phosphate reacts with stannous chloride molybdenum solutions to give a blue color, which intensity was measured at (618) $\mathrm{nm}$.

Activity was calculated as following:

$5^{\prime}-\mathrm{NT}$ activity $(\mathrm{U} / \mathrm{L})=\frac{\mathrm{A}_{\text {test }}-\mathrm{A}_{\text {control }}}{\mathrm{A}_{\text {sdd }}} \times \frac{1}{\mathrm{~V}_{\mathrm{s}}} \times \frac{\mathrm{V}_{\text {std }}}{1} \times \frac{\text { std.conc. }}{1} \times \frac{1}{\mathrm{t}}$

Where:
$\mathrm{V}_{\mathrm{S}}=$ Sample volume.

$\mathrm{V}_{\text {std. }}=$ Standard volume .

Std.conc. $=$ Concentration of standard solution.

$\mathrm{t}=$ Incubation time.

\section{Expression of the enzymes activities:}

For all determined enzymes, International unit was used to express their activities. Enzyme activity unit is defined as the amount of the enzyme that catalyzes the hydrolysis of one micromole of substrate per minute per liter of serum under optimum conditions. Their specific activities were expressed as enzyme unit per mg of protein.

\section{Evaluation of results:}

The results were subjected to statistical evaluation by means of the student's t-test. A difference between means giving a probability of less than $5 \%$ was considered as statistically significant.

\section{Results \& Discussion:}

The activities of selected enzymes of purine metabolism were measured in sera of ovarian cancer patients, and compared with those of benign ovarian tumors and normal women, before surgery, and after first course of chemotherapy.

The results in Table (1) show the ADA activity level in sera of control women, and those of patients with benign and malignant ovarian tumors. It is obvious from the results that no significant change $(\mathrm{P}<0.05)$ was observed in this enzyme activity in sera of women with benign ovarian tumors in comparison with that of control women. While a significant increase in this enzyme specific activity was observed in patients with malignant tumor $(\mathrm{P}<0.05)$.

When the comparison were carried out for the activities of AMPDA and 5'-NT between sera of 
control women, patients with benign and malignant ovarian tumors, A significant reduction in these enzymes specific activities was observed $(\mathrm{p}<0.05)$ Table (1).

Table (1): ADA, AMPDA, 5' - 'NT specific activities in sera of control women, and patients with benign and malignant ovarian tumors before surgery

\begin{tabular}{|c|c|c|c|c|c|c|}
\multicolumn{2}{c|}{} & \multicolumn{3}{c|}{$\begin{array}{c}\text { Specific activities mU/mg } \\
\text { mean }( \pm \text { SD })\end{array}$} \\
\hline Group & No. & $\begin{array}{c}\text { Age } \\
(\text { year })\end{array}$ & Total protein g/dL & ADA & AMPDA & 5 '-NT \\
\hline Control & 27 & $18-73$ & $\begin{array}{c}7.12 \\
( \pm 0.97)\end{array}$ & $\begin{array}{c}0.270 \\
( \pm 0.091)\end{array}$ & $\begin{array}{c}0.107 \\
( \pm 0.009)\end{array}$ & $\begin{array}{c}0.152 \\
( \pm 0.023)\end{array}$ \\
\hline Benign ovarian tumors & 24 & $20-66$ & $\begin{array}{c}7.23 \\
( \pm 0.81)\end{array}$ & $\begin{array}{c}0.281 \\
( \pm 0.007)\end{array}$ & $\begin{array}{c}0.098 \\
( \pm 0.044)\end{array}$ & $\begin{array}{c}0.148 \\
( \pm 0.003)\end{array}$ \\
\hline Ovarian cancer & 6 & $19-71$ & $\begin{array}{c}7.09 \\
( \pm 1.36)\end{array}$ & $\begin{array}{c}0.503 \\
( \pm 0.049)\end{array}$ & $\begin{array}{c}0.032 \\
( \pm 0.017)\end{array}$ & $\begin{array}{c}0.022 \\
( \pm 0.016)\end{array}$ \\
\hline
\end{tabular}

In order to check the variation of the above sited enzymes activities after chemotherapy, their activities and specific activities were followed after one course of treatment with methotrexate and (5-Fu), where (2) patients were given a methotrexate dose and (4) patients were given a (5-
$\mathrm{Fu}$ ) dose after one month of the surgery.

The results in Table (2) show that a significant decrease in ADA specific activity, while a significant increase in AMPDA and 5'-NT specific activities were present after the treatment in comparison with those results before surgery.

Table (2): ADA, AMPDA, 5'-NT specific activities in sera of control women, and patients with benign and malignant ovarian tumors after chemotherapy.

\begin{tabular}{|c|c|c|c|c|c|}
\cline { 3 - 5 } \multicolumn{2}{c|}{} & \multicolumn{3}{c|}{$\begin{array}{c}\text { Specific activities mU/mg } \\
\text { mean }( \pm \text { SD })\end{array}$} \\
\hline Ovarian cancer group & No. & Total protein g/dL & ADA & AMPDA & $5^{\prime}-\mathrm{NT}$ \\
\hline Before surgery & 6 & $\begin{array}{c}7.09 \\
( \pm 1.36)\end{array}$ & $\begin{array}{c}0.503 \\
( \pm 0.049)\end{array}$ & $\begin{array}{c}0.032 \\
( \pm 0.017)\end{array}$ & $\begin{array}{c}0.022 \\
( \pm 0.016)\end{array}$ \\
\hline After chemotherapy & 6 & $\begin{array}{c}6.058 \\
( \pm 0.032)\end{array}$ & $\begin{array}{c}0.301 \\
( \pm 0.003)\end{array}$ & $\begin{array}{c}0.073 \\
( \pm 0.005)\end{array}$ & $\begin{array}{c}0.0908 \\
( \pm 0.007)\end{array}$ \\
\hline
\end{tabular}

The interest in the enzymes studied in this project, is due to their importance in nucleotide metabolism, and in metabolic processes of nucleic acid and nucleoproteins; as well as to their reported regulation role in the metabolism[19,20], in coronary blood flow, vasodilation, and cardioprotection [21].
Increased synthesis of RNA and DNA is one of the biochemical changes that often observed in cancer cells. Such increase may account for increase utilization of purine and pyrimidine bases by such cells. This in-turn is reflected by the variation in the activities of the enzymes involved in their metabolism[22,23]. 
The increase in ADA activity that was observed in this study (Table 1) in sera of patients with malignant ovarian tumors can be regarded as a local activation of cellular immune response[24, 25, 26].

Moreover this increase is essential for cancer cells to cope with the accelerated purine metabolism that recorded to take place in cancerous tissues $[27,28,29]$. The enzyme escape through the membrane of the tumor cells, which one of its reported biochemical changes is the increase of membrane permeability, into extracellular fluid [24]Other research suggest that low activity of ADA observed in saliva of the patients with oral cancer may be a compensatory mechanism against rapid purine and DNA metabolism in cancer cells. The current study does not support the hypothesis that saliva's activities of these enzymes may be used as additional diagnostic and prognostic cancer markers [30]. While other research suggest that These marker enzymes such as AHH, g -GT, 5'-NT, LDH and ADA are specific indicators of lung damage [15] .

High ADA activity may be due to its role in the detoxification process of high amount of toxic adenosine and deoxyadenosine substrates provided from accelerated purine metabolism in cancer tissue [27]. Increased ADA activity may be a compensatory mechanism against toxic accumulation of its substrates due to accelerated purine and pyrimidine metabolism in the cancerous tissues and cells [29]. Also has been reported that the patients with lung cancer were shown to have elevated serum ADA levels[15].

Adenosine is known to be associated with effects such as inhibition of immune response, so its level is under close regulation by different enzymes at different levels [31].
The reaction which is catalyzed by AMPDA reflects the enzyme regulatory properties. This serve to protect the cancer cells against the sharp decrease in the adenylate energy charge, by AMP generation, when the rate of ATP utilization is suddenly increased in such cells. So, at low energy charge, a decrease in the size of the adenine nucleotide pool cause a marked and nonlinear decrease in the rate of the deaminase reaction [32]. This serves to prevent excessive depletion of the adenine nucleotide pool.

$5^{\prime}-\mathrm{NT}$, one of the enzymes studied in this work, has been always regarded as linked to maturation [32]. The low activity of this enzyme that reported in this study (Table 1) could be due to presence of fewer normally active molecules in cancer cells or to the production of an altered enzyme because of genomic transcriptional or post translational modifications in such cells [33]. While increased activity of $5^{\prime}$-NT seems to have originated from the proliferating tumor cells, a fast moving $5^{\prime}$-NT is found to be elevated in metastases to liver from tumor of the lung and breast [15].

Most anticancer drugs, in particular those which are "cytotoxic", are antiproliferative. Furthermore, they affect all rapidly dividing normal tissue. So they likely to have toxic effects such as myelotoxicity with decreased leucocyte production and thus decrease resistance to infection [3]. So the decrease in ADA activity was observed (Table 2) after chemotherapy since a causal relationship had been found between lack of ADA and aberration of the immune system [26, 33, 34]. While other research suggested The reduction in ADA activity indicates that it may act to control nucleotide levels and it may also be speculated that surgery 
causes greater platelet activation contributing to the changes seen in the conization groups[35].

Another toxic effect of the drugs is rapid cell destruction with extensive purine catabolism. Such effect may be observed by the increase in AMPDA and 5'-NT activities that was measured after the chemotherapy treatment (Table 2). The increase in AMPDA activity could be due to its role in stabilizing the adenylate energy charge after such treatment [32]. Another reason for such increase in $5^{\prime}-\mathrm{NT}$ activity after the treatment may be due that $5^{\prime}$-NT contributes in achieving an appropriate modulation of the drugs delivery rate through the dephosphorylating machinery [33].

On the other hand such increase in AMP metabolic enzyme activities (AMPDA and 5'-NT) might be due to the decrease in ADA activity after chemotherapy, so in-order to predisposed the adenosine accumulation in cancer cell, an increase in AMPDA and $5^{\prime}-\mathrm{NT}$ activities occur.

\section{References:}

1-Weber G. 1983. Enzymes of purine metabolism in cancer. Clin.Biochem., 16 (1): 57- 63.

2-Carlucci F., Rosi F., Pietro Di C., Marinello E., Pizzichini M., and Tabucchi A. 1997. Purine nucleotide metabolism: specific aspects in chronic lymphocytic leukemia lymphocytes. Biochem. Biophys. Acta., 1366: 203-210.

3-Scholar E.M., and Calabresi P. 1973. Identification of the enzymatic path -ways of nucleotide metabolism in human lymphocytes and leukemia cells. Cancer Res., 33: 94-103.

4-O'Regan, M. 2005. Adenosine and the regulation of cerebral blood flow. Neurol. Res. 27: 175-181.
5-Willems, L., Ashoton, K.J., and Headrick, J.P. 2005. Adenosinemediated cardioprotection in the aging myocardium. Cardiovasc. Res.66: 245-255.

6-Ribeiro, J.A. 2005. What can adenosine neuromodulation do for

neuroprotection? Curr. Drug Targets CNS Neurol. Disord. 4: 325-329.

7-Vallon, V., Muhlbauer, B., and Osswald, H. 2006. Adenosine and kidney function. Physiol. Rev. 86: 901-940.

8-Adair T.H., 2005. Growth regulation of vascular system. Am.J. physiol., regulation integration comparative, 289: 283-296.

9-Vivet-Boudou, V., Diierjean, J., Isel, C., and Marquet, R. 2006. Nucleoside and nucleotide inhibitors of HIV-1 replication. Cell. Mol. Life Sci. 63: 163-186.

10-Jennifer B. Rose and Imogen R. Coe 2008. Physiology of Nucleoside Transporters: Back to the Future. Physiology, 23(1): 4148.

11-Pastor-Anglada, M., Cano-Soldado, P., Molina-Arcas, M., Lostao, M.P., Larrayoz, I., MartinezPicado, J., and Casado, F.J. 2005. Cell entry and export of nucleoside analogues. Virus Res. 107: 151164.

12-Damaraju, V.L., Damaraju, S., Young, J.D., Baldwin, S.A., Mackey, J., Sawyer, M.B., and Cass, C.E. 2003. Nucleosides anticancer drugs: the role of nucleoside transporters in resistance to cancer chemotherapy. Oncogene, 22: 7524-7536.

13-Spratlin, J., Sangha, R., Glubrecht, D., Dabbagh, L., Young, J.D., Dumontet, C. 2004. The absence of human equilibrative nucleoside transporter 1 is associated with reduced survival in patients with gemcitabine-treated

pancreas 
adenocarcinoma. Clin. Cancer Res. 10: 6956-6961.

14- Borzenko ,B., Shatova,O., Zhuravel,T., Verchova, O., Sedakov, I., Zinkovich, I. 2008. The use of DNA metabolism enzyme activity dynamics as a testsystem in Breast cancer management and treatment. Annales 21 (2): 179-181.

15- Kamaraj,S., Vinodhkumar, R., Anandakumar, P., Jagan, S., Ramakrishnan ,G., Devaki,T. 2007. The effects of Quercetin on antioxidant status and tumor markers in the lung and serum of mice treated with Benzo(a)pyrene. Biological \& Pharmaceutical Bulletin, 30(12): 2268 -2273.

16-Lowry O.H., Rosebrough N.J., Farr A.I., Randall R.J. 1951. Protein measurement with the Folin phenol reagent. J.Biol. Chem., 193: 265275.

17-Giusti G., Galanti B., Mncini A. 1970. Serum guanase activity in viral hepatitic and some other hepatic and extrahepatic disease. Enzymologia, 38: 373-378.

18-Wood R.J., Williams D.G. 1981. Colorimetric determination of serum 5'-nucleotidase without deproteinization. Clin.Chem., 27 (3): 464-465.

19-Schrader W.P., Stacy A.R., Pollar B. 1976. Purification of human ADA by affinity chromatography. J.Biol.Chem., 251(13): 4026-4032.

20-Gennip van A.H. 1999. Defects in metabolism of purine and pyrimidines. Ned.Tijdschr Klin. Chem., 24: 171-175.

21-Peart JN, Headrick JP. 2007. Adenosinergic cardioprotection: Multiple receptors, multiple pathways. Pharm Therap 114: 208221.

22-Calucci F., Rosi F., Dipietro C., Marinello E., Pizzichini M., Tabucchi M. 1997. Aspects in chronic lymphocytic leukemia. Biochem. Biophys. Acta, 1360: 203-210.

23-Ungerer J.P.J., Grobler S.M. 1988. Molecular forms of Adenosine deaminase in pleural effusions. Enzyme, 40: 7-13.

24-Bondy P.K., andRosenberg L.E. 1980. "Metabolic control and diseases". Saunders W.B. Company; $8^{\text {th }}$ edition UK, pp777937.

25-Namiot Z., Stasiewicz J., Namiot A. , Kemona A., Kralisz M., Gorski J. 1996. ADA activity in patients with the intestinal type of gastric carcinoma. Cancer Lett., 109: 199202.

26-Eroglu A., Canbolat O., Demirci S. 2000. Activities of adenosine deaminase and 5'- nucleotidase in cancerous and noncancerous human colorectal tissues. Med. Oncol., 17(4): 319-324.

27-Durak I., Perk H., Kavultu M., Canbolat O., Akyol O., Beduk Y. 1994. ADA, 5'-NT, XO, SOD, and Catalase activities in cancerous and non cancerous human bladder tissues. Free Radical Biol., 16: 825831.

28-Ozturk H.S., Karaayvaz M., Kacmaz M., Kavatcu M., Akgul H., Durak I. 1998. Activities of the enzymes participating in purine and free radical metabolism in cancerous human colorectal tissue. Cancer Biochem. Biophys., 16 (12): 157-168.

29-Moriwaki Y., Ymamoto T., Higshino K. 1999. Enzymes involved in purine metabolism. Histol. Histopathol., 14 (4): 13211340.

30- Saracoglu, U 1; Guven, O 2; Durak, I 3 2005.Adenosine deaminase and 5'-nucleotidase activities in saliva from patients with oral and laryngealcancer. Oral Diseases, 11 (5): 323-325. 
31-Vannoni D., Beinini A., Carlucci F., S., Dipietro M.C., Lenoncini R., Rose F., Tabucchiu E., Tanzini G., Mannello E. 2004. Enzyme activities controlling adenosine levels in normal and neoplastic tissues. Med. Oncology, 21(2): 186-196.

32- Rosi F. , Agostinho A.B. , Carlucci F. , Zanoni L. , Porcelli B. , Marinllo E. , A. Tabucchiu E. 1998. Behavior of human lymphocytic isoenzyme of $5^{\prime}$-NT. Life Science, 62 (25): 2257-2266.

33-Giblett E.L. Aderson,J.E. , Cohen F. F. , Pollara B., Meuwissen H.J. 1972. Adenosine deaminase deficiency in two patients with severely impaired cellular immunity. Lancet, 2: 1067-1069.

34-Dissing J., Knudesn B. 1972. Adenosine deaminase deficiency and combined immunodeficiency syndrome. Lancet, 2: 1316-1320.

35-Acosta Maldonado,P., de Carvalho Corrêa, M., Vargas Becker,L., Flores, C., BeatrizMoretto,M.,Vera Morsch,V.,ChitolinSchetinger,M.R .2008.Ectonucleotide

Pyrophosphatase/

Phosphodiesterase (E-NPP) and Adenosine deaminase (ADA) activities in patients with uterine cervix neoplasia. Clinical Biochemistry, 41 (6): 400-406.
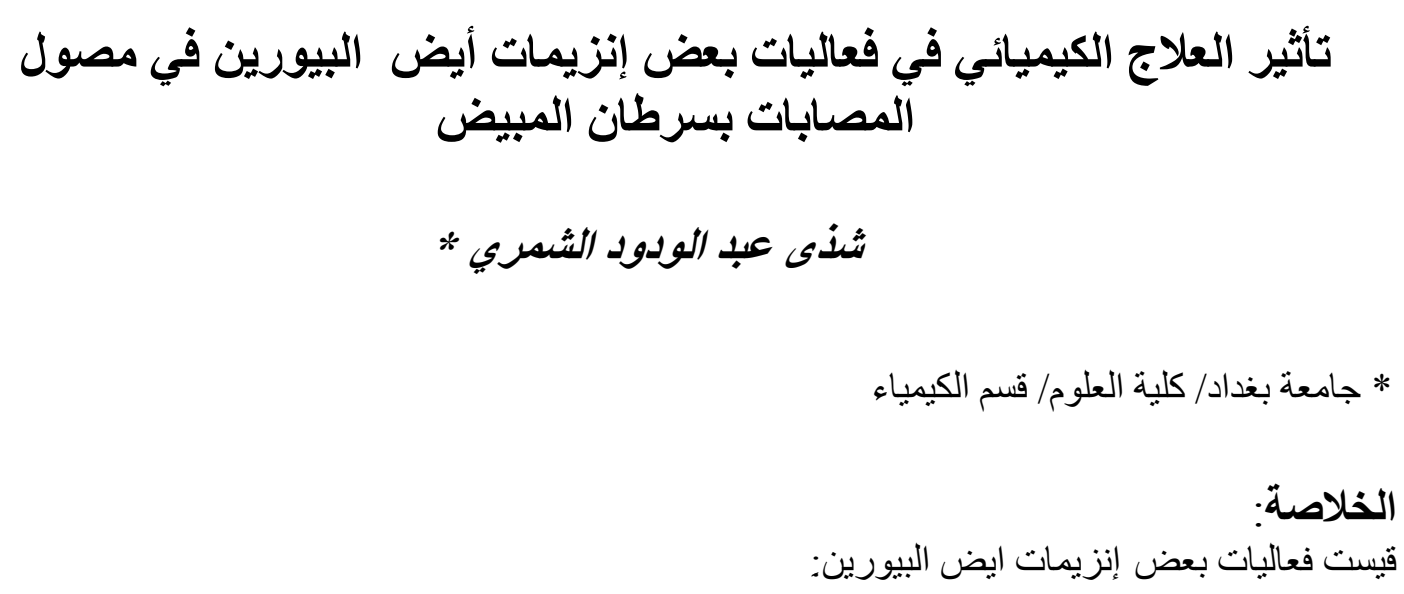

Adenosine deaminase (ADA; Ec: 3.5.4.4), 5'- Nucleotidase (5'- NT; Ec: 3.1.3.5), and AMP - amino hydrolase (AMP - deaminase AMPDA; Ec: 3.5.4.6) في مصول المصابات بسرطان المبيض ، قبل العملية ، ومقارنتها بالمصابات بأورام المبيض الحميدة العيات عندالنساء

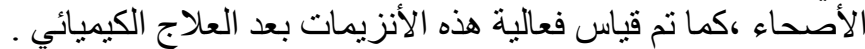

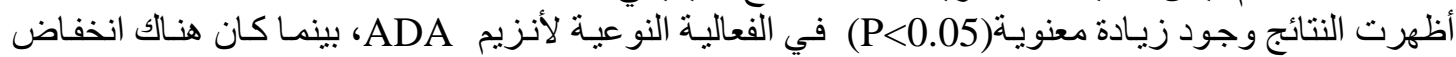
معنوي (P<0.05)في الفعالية النوعية لكل من إنزيم AMPDA و

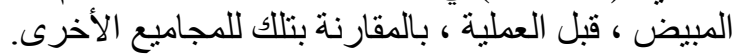

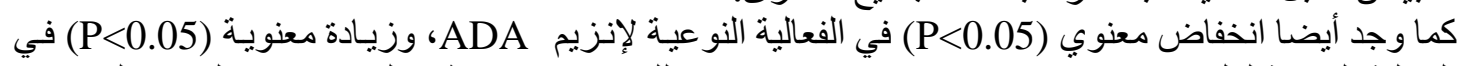

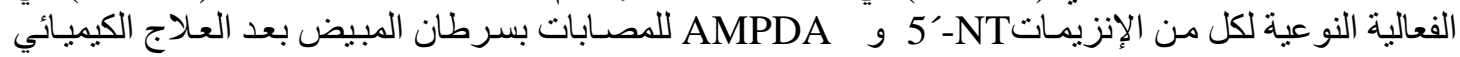
بالمقارنة بتلك للمجمو عة نفسها قبل الإنزيت العملية. 